\title{
Aplikasi Sinbiotik Untuk Resistensi Udang Vaname Litopenaeus vannamei Terhadap Virus Infectious Myonecrosis
}

\section{(Synbiotic Application For Resistance Of Vanammei Shrimp Litopenaeus vannamei On Infectious Myonecrosis Virus)}

\author{
Wida Lesmanawati' ${ }^{1}$, Widanarni ${ }^{2)}$, Sukenda ${ }^{2)}$ \\ ${ }^{1}$ Program Diploma, Institut Pertanian Bogor, Jl. Kumbang No 14 Bogor \\ ${ }^{2}$ Departemen Budidaya Perairan, Institut Pertanian Bogor, Jl. Raya Dramaga Bogor \\ Email : wida.lesmanawati@gmail.com
}

\begin{abstract}
The culture of vaname shrimp can not be separated from various outbreaks of diseases, especially by viral infections including Infectious Myonecrosis (IMN) which has caused the cumulative death of vaname shrimp up to $70 \%$. One effort to prevent diseases in shrimp is by applying synbiotics. This study aims to evaluate the synergistic effects of probiotic bacteria SKT-b and oligosaccharides extracted from sweet potatoes, in increasing resistance to IMN disease. Shrimp are treated with synbiotic feed with different prebiotic concentrations of $1 \%$ (Pro + Pre 1\%), 2\% (Pro + Pre 2\%) and 3\% (Pro + Pre 3\%). Feed treatment was given to the shrimp (weight $\pm 1.9 \mathrm{~g}$ ) for 30 days. Then the shrimp were infected with the IMN virus and carried out observations for 10 days including survival parameters, clinical symptoms, total hemocytes and phenoloxidase activity. Application of synbiotic can increase vaname shrimp resistance to IMN virus infection. This increase is indicated by the increase in survival of shrimp and the decrease in the rate of infection from IMN, observed through clinical symptoms. One of the improvements in shrimp immune response was due to an increase in total leukocytes and phenoloxidase activity. In general, the treatment of Pro + Pre $2 \%$ and Pro + Pre $3 \%$ showed a better response to the increase in resistance of vaname shrimp compared to other treatments.
\end{abstract}

Key words : immune response, IMN disease, sweet potattos Ipomoea batatas, synbiotic, vaname shrimp Litopenaeus vannamei.

\begin{abstract}
ABSTRAK
Budidaya udang vaname tidak lepas dari berbagai wabah penyakit yang menyerang, terutama oleh infeksi virus diantaranya Infectious Myonecrosis (IMN) yang telah menyebabkan kematian kumulatif udang vaname hingga $70 \%$. Salah satu upaya pencegahan penyakit pada udang adalah dengan aplikasi sinbiotik. Penelitian ini bertujuan untuk mengevaluasi efek sinergis dari bakteri probiotik SKT-b dan oligosakarida hasil ekstraksi dari ubi jalar, dalam meningkatkan resistensi terhadap penyakit IMN. Udang diberi perlakuan pakan sinbiotik dengan konsentrasi prebiotik berbeda yaitu 1\% (Pro+Pre 1\%), 2\% (Pro+Pre 2\%) dan 3\% (Pro+Pre 3\%). Pakan perlakuan diberikan ke udang uji (bobot $\pm 1.9 \mathrm{~g}$ ) selama 30 hari. Selanjutnya udang uji diinfeksi dengan virus IMN dan dilakukan
\end{abstract}


pengamatan selama 10 hari meliputi parameter sintasan, gejala klinis, total hemosit dan aktifitas phenoloksidase. Aplikasi pemberian sinbiotik mampu meningkatkan resistensi udang vaname terhadap infeksi virus IMN. Peningkatan resistensi ini ditandai dengan meningkatnya sintasan udang dan menurunnya tingkat infeksi dari IMN yang diamati melalui gejala klinis. Peningkatan respon imun udang salah satunya dikarenakan peningkatan total leukosit dan aktivitas phenoloksidase. Secara umum, perlakuan Pro+Pre 2\% dan Pro+Pre 3\% menunjukkan respon yang lebih baik terhadap peningkatan resistensi udang vaname dibandingkan dengan perlakuan lainnya.

Kata kunci : respon imunitas, penyakit IMN, ubi jalar Ipomoea batatas, sinbiotik, udang vaname Litopenaeus vannamei.

\section{PENDAHULUAN}

Udang vaname Litopenaeus vannamei merupakan komoditas unggul budidaya. Udang ini diintroduksi ke Indonesia tahun 1999 hasil impor dari Taiwan dan Hawai. sampai akhir tahun 2007, budidaya udang ini menyebar cepat ke berbagai daerah dan telah dibudidayakan sekurangnya di 17 provinsi di Indonesia. Komoditas ini telah menggantikan udang windu yang mengalami kegagalan akibat penyakit white spot disease (WSD) (Taukhid dan Nura'ini 2008). Dalam perkembangannya, budidaya udang vaname di Indonesia juga tidak lepas dari berbagai wabah penyakit yang menyerang, terutama oleh infeksi virus. Peyakit virus yang sering menyerang diantaranya WSD, yellow head disease (YHD), infectious myonecrosis (IMN), taura syndrome virus (TSV) dan infectious hypodermal and hematopoietic necrosis virus (IHHNV).

Wabah IMN pertama kali menyerang budidaya udang vaname di Situbondo pada pertengahan tahun 2006 (Taukhid dan Nura'ini 2008). Wabah tersebut kemudian menyebar cepat ke berbagai daerah di Indonesia dan telah menyebabkan kematian kumulatif udang vaname hingga $70 \%$. Sampai saat ini belum ditemukan pengobatan yang efektif untuk penyakit viral pada udang. Penelitian mengenai penanggulangan penyakit IMN belum banyak dilakukan. Selama ini upaya penanggulangan wabah IMN dilakukan dengan cara menghindari masuknya agen penyakit melalui biosekuriti, penggunaan benih specific pathogen free (SPF), mengurangi kepadatan, monitoring penyakit dan manajemen budidaya yang baik. Penggunaan herbal, imunostimulan dan probiotik juga banyak dilakukan untuk meningkatkan imunitas udang sebagai upaya pencegahan penyakit.

Probiotik banyak menarik perhatian untuk tujuan penelitian maupun komersial. Salah satu bakteri yang potensial sebagai probiotik telah berhasil diisolasi dari pakan udang Skeletonema yaitu bakteri SKT-b. Hasil analisis sekuen sebagian gen 16S-rRNA menunjukkan bahwa bakteri tersebut termasuk spesies Vibrio alginolyticus dengan indek kemiripan 88\% (Widanarni et al. 2003). Bakteri SKT-b mampu menekan populasi bakteri $V$. harveyi, meningkatkan sintasan larva udang windu yang terinfeksi vibriosis, dan mampu menstimulasi sistem imunitas udang vaname (Widanarni et al. 2003; Widanarni et al. 2008; Syahailatua 2009). 
Aplikasi probiotik yang diberikan bersamaan dengan prebiotik terbukti memberikan hasil yang lebih baik dibandingkan bila diaplikasikan secara terpisah (Li et al. 2009; Rodriguez-Estrada et al. 2009; Zhang et al. 2010). Ubi jalar mengandung oligosakarida tidak dicerna (non-digestible oligosaccharides [NDOs]) diantaranya rafinosa dan sukrosa yang berfungsi sebagai prebiotik (Marlis 2008; Putra 2010; Haryati dan Supriyati 2010). Menurut Lesmanawati et al. (2013), ekstrak oligosakarida tepung ubi jalar (berumbi putih) mentah mengandung rafinosa $0.07 \%$ dan sukrosa $2.46 \%$. Namun kandungan oligosakarida ini akan berbeda jika preparasi berbeda. Pengukusan meningkatkan konsentrasi rafinosa menjadi sebesar $2.62 \%$ dan sukrosa sebesar 17.09\%. Lebih lanjut, Lesmanawati et al. (2013) dan Lesmanawati et al. (in press) membuktikan bahwa oligosakarida pada ekstrak ubi jalar tersebut secara in vitro dapat menunjang pertumbuhan bakteri skt-b, dan secara in vivo dapat meningkatkan bakteri di usus udang vaname. Penelitian ini bertujuan untuk mengevaluasi efek sinergis dari bakteri probiotik SKT-b dan oligosakarida hasil ekstraksi dari ubi jalar, dalam meningkatkan resistensi terhadap penyakit IMN.

\section{METODE PENELITIAN}

\section{Preparasi dan Ekstraksi Oligosakarida}

Ubi jalar (Ipomoea batatas) berumbi putih dikukus selama 30 menit, diiris tipis dan dikeringkan dalam oven suhu $50{ }^{\circ} \mathrm{C}$ selama 2 hari, kemudian ditepungkan. Tepung ubi jalar diekstraksi dalam etanol $70 \%$ dengan perbandingan 1:10 dan digoyang dalam shaker (kecepatan $120 \mathrm{rpm}$ suhu $30^{\circ} \mathrm{C}$ ) selama 15 jam Muchtadi (1989). Filtrat yang telah disaring kemudian dikeringkan dengan frezze dryer. Ekstrak oligosakarida hasil freeze dry kemudian dianalisis menggunakan High Performance Liquid Chromatography (HPLC), untuk mengetahui jenis dan konsentrasi oligosakarida yang terkandung dalam ekstrak. Hasil anallisis HPLC menunjukkan total ekstrak oligosakarida dalam ubi jalar hasil frezze drying sebesar $64.86 \%$, yang terdiri dari sukrosa $52.86 \%$, rafinosa 8.14\% dan maltoheptaosa 3.86\% (Lesmanawati et al. 2013).

\section{Preparasi Pakan Perlakuan}

Bakteri SKT-b yang akan diberikan ke udang, sehari sebelumnya dikultur di media SWC cair selama 16 jam dalam waterbath shaker (kecepatan 140 rpm, suhu $29^{\circ} \mathrm{C}$ ). Pelet bakteri diambil dengan menggunakan sentrifuse kecepatan 10 000 rpm selama 5 menit. Pelet bakteri dicampurkan ke pakan sebanyak $10^{10}$ $\mathrm{cfu} / \mathrm{g}$ pakan. Binder yang digunakan berupa gelatin sebanyak 3\% dari bobot pelet. Bakteri SKT-b dan ekstrak ubi jalar sesuai dosis perlakuan ditambahkan ke pakan, kemudian dikeringanginkan selama 30 menit dan segera diberikan ke udang.

\section{Kondisi Udang Uji}

Udang vaname dengan bobot rataan $1.9 \mathrm{~g}$ dipelihara di akuarium (volume $54 \mathrm{~L})$ sebanyak 40 ekor per akuarium. Akuarium perlakuan dilengkapi dengan shelter dan anco, serta ditutup plastik hitam untuk mengurangi intensitas cahaya. Media pemeliharaan udang diaerasi terus menerus selama perlakuan. Akuarium 
dengan perlakuan yang sama digabung dalam satu sistem resirkulasi untuk mempertahankan kualitas air media pemeliharaan udang.

\section{Pengujian Resistensi Udang Vaname terhadap Infeksi Virus IMN}

Uji ini dilakukan untuk mengevaluasi kinerja sinbiotik dalam meningkatkan resistensi udang vaname yang diinfeksi virus IMN. Pengujian terdiri dari lima perlakuan dengan tiga ulangan, sebagai berikut:

Kontrol (-) : Udang vaname diberi pakan komersil dan diinjeksi PBS.

Kontrol (+) : Udang vaname diberi pakan komersil dan diinfeksi IMN.

Pro+Pre 1\%: Udang vaname diberi pakan komersil dengan penambahan probiotik dan prebiotik $1 \%$ serta diinfeksi IMN.

Pro+Pre 2\%: Udang vaname diberi pakan komersil dengan penambahan probiotik dan prebiotik $2 \%$ serta diinfeksi IMN.

Pro+Pre 3\%: Udang vaname diberi pakan komersil dengan penambahan probiotik dan prebiotik $3 \%$ serta diinfeksi IMN.

Udang diberi pakan perlakuan setiap hari selama 30 hari dengan FR sebanyak $6 \%$ dan frekuensi pemberian pakan 4 kali sehari. Udang uji sebanyak 18 ekor per akuarium kemudian diinfeksi dengan virus IMN melalui injeksi sebanyak $0.1 \mathrm{~mL}$ per ekor (kecuali perlakuan Kontrol (-)). Infeksi IMN dilakukan dengan menginjeksikan hasil ekstraksi tubuh udang yang positif terinfeksi IMN berdasarkan pengamatan gejala klinis dan hasil analisis PCR. Ekstraksi virus IMN dari sampel udang yang positif terinfeksi dilakukan berdasarkan metode menurut Escobedo et al. (2006).

Udang yang diinfeksi virus IMN, pada masing-masing akuarium sebanyak 15 ekor digunakan untuk pengukuran parameter sintasan dan gejala klinis serta 3 ekor untuk pengukuran parameter imunitas. Selama waktu pengamatan, udang diberi pakan kontrol (tanpa penambahan sinbiotik) dengan metode dan frekuensi yang sama seperti saat perlakuan. Aerasi, penyifonan dan pergantian air dilakukan untuk mempertahankan kualitas air. Pengamatan dilakukan selama 10 hari setelah infeksi. Parameter yang diamati meliputi sintasan, gejala klinis serta parameter imunitas udang berupa total hemosit dan aktivitas phenoloxidase. Sintasan dan gejala klinis diamati pada hari ke 10 setelah infeksi, sedangkan total hemosit dan aktivitas phenoloxidase diamati pada hari ke 0 (sebelum infeksi), hari ke 5 dan 10 setelah infeksi.

\section{Parameter Pengamatan}

a. Sintasan (SR)

Sintasan udang dihitung dengan menggunakan rumus berikut:

Keterangan :

$$
\mathrm{SR}=(\mathrm{Nt} / \mathrm{No}) \times 100 \%
$$

$\mathrm{Nt}$ : Jumlah udang yang hidup pada akhir pengamatan (ekor) 
No : Jumlah udang pada awal pengamatan (ekor)

b. Gejala Klinis

Gejala klinis yang timbul pada udang dapat menunjukkan tingkat infeksi dari IMN tersebut. Data gejala klinis yang dihasilkan berupa kualitatif (deskriptif) dan kemudian dibuat semi kuantitatif dengan cara skoring. Pengelompokan gejala klinis ditentukan berdasarkan Hasan (2011) dengan sedikit modifikasi (Tabel 1 dan Gambar 1)

Tabel 1 Pengelompokan tingkat infeksi IMNV terhadap udang vaname berdasarkan gejala klinis yang muncul

\begin{tabular}{|c|c|c|}
\hline Level & Gejala Klinis & $\begin{array}{l}\text { Tingkat } \\
\text { Infeksi }\end{array}$ \\
\hline 1 & Terinfeksi tanpa gejala klinis & Ringan \\
\hline 2 & $\begin{array}{l}\text { Sedikit warna putih lebam di dalam jaringan di } \\
\text { beberapa segmen abdomen }\end{array}$ & Sedang \\
\hline 3 & $\begin{array}{l}\text { Sebagian besar jaringan abdomen berwarna putih } \\
\text { lebam }\end{array}$ & Berat \\
\hline 4 & $\begin{array}{l}\text { Bagian abdomen dari arah ekor berwarna merah } \\
\text { (jaringan mati) }\end{array}$ & Sangat berat \\
\hline
\end{tabular}

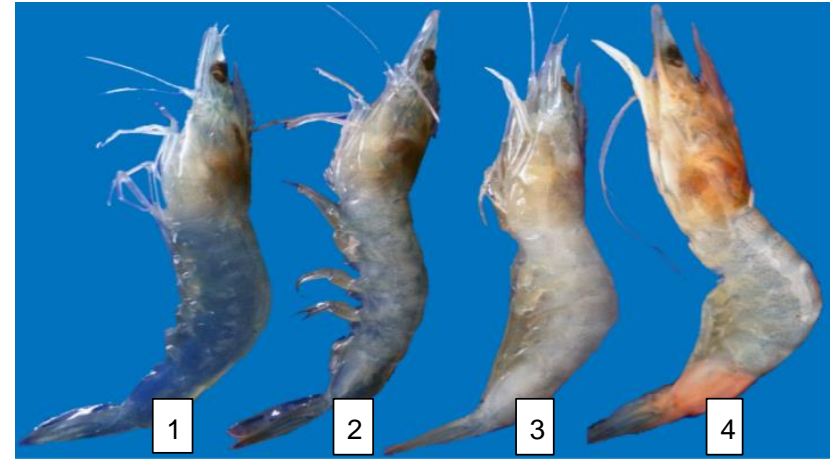

Gambar 1 Gejala klinis udang yang terinfeksi virus IMN. Angka menunjukkan tingkat infeksi ringan (1), sedang (2), berat (3), dan sangat berat (4)

c. Total Hemosit

Pengukuran total hemosit (THC) dilakukan berdasarkan metode Blaxhall dan Daishley (1973). Hemolimph sebanyak $0.1 \mathrm{~mL}$ yang sudah ditambahkan antikoagulan, dihitung dengan menggunakan hemasitometer pada mikroskop perbesaran 400 kali. Perhitungan nilai THC menggunakan rumus berikut :

Total hemosit $=\Sigma$ sel terhitung $\mathrm{x}(\mathrm{vol} . \text { hemasitometer })^{-1} \mathrm{x}$ pengenceran

d. Aktivitas Phenoloxidase (PO)

Pengukuran PO dilakukan berdasarkan Liu dan Chen (2004). Aktivitas PO diukur berdasarkan formasi dopachrome yang dihasilkan oleh L-DOPA. Hemolimph yang sudah dicampur dengan antikoagulan sebanyak $1 \mathrm{~mL}$ 
disentrifus ( 1.500 rpm; suhu $4^{\circ} \mathrm{C}$ ) selama 10 menit. Supernatan dibuang dan pelet disuspensikan kembali secara perlahan ke dalam $1 \mathrm{~mL}$ larutan cacodylate-citrate buffer, selanjutnya disentrifus kembali. Pelet diambil dan disuspensikan dalam $200 \mu \mathrm{L}$ cacodylate-citrate buffer. Suspensi sel sebanyak $100 \mu \mathrm{L}$ diinkubasi dengan $50 \mu \mathrm{L}$ trypsin $\left(1 \mathrm{mg} \mathrm{ml}^{-1}\right.$ cacodylatecitrate buffer) selama 10 menit pada suhu $25-26{ }^{\circ} \mathrm{C}$. Selanjutnya ditambahkan $50 \mu \mathrm{L}$ L-DOPA ( $3 \mathrm{mg} \mathrm{mL}^{-1}$ cacodylate-citrate buffer) setelah 5 menit, dan ditambahkan $800 \mu \mathrm{L}$ cacodylate-citrate buffer. Densitas optikal (optical density) diukur dengan menggunakan spektrofotometer pada panjang gelombang $490 \mathrm{~nm}$. Larutan standar mengandung $100 \mu \mathrm{L}$ suspensi hemosit, $50 \mu \mathrm{L}$ cacodylate-citrate buffer (pengganti tripsin) dan $50 \mu \mathrm{L} \mathrm{L}$ DOPA yang digunakan untuk mengukur background aktivitas PO pada semua larutan uji. Aktivitas PO dihitung berdasarkan rumus berikut:

$$
\text { Aktivitas PO }=\frac{(\text { Absorban sampel }- \text { Absorban blanko }) \times 1000}{n L \text { sampel PO } \times \frac{\mu L \text { hemolimph }}{\mu L \text { hemaolimph }+\mu L \text { antikoagulan }}}
$$

\section{Prosedur Analisis Data}

Percobaan menggunakan Rancangan Acak Lengkap (RAL) dengan satu faktor. Analisis data dilakukan dengan metode analisis ragam (analysis of variance/ANOVA) pada selang kepercayaan 95\% ( $\alpha=0.05)$. Apabila terdapat perbedaan antar perlakuan maka analisis dilanjutkan dengan uji Tukey menggunakan software IBM SPPS Statistics version 19.

\section{HASIL DAN PEMBAHASAN}

\section{Sintasan dan Gejala Klinis}

Infeksi virus IMN melalui injeksi menyebabkan penurunan nilai sintasan udang vaname paling rendah pada Kontrol (+) sebesar $17.78 \%$ dibandingkan dengan Kontrol (-) sebesar 93,33\% pada hari ke 10 setelah infeksi. Pemberian sinbiotik dapat meningkatkan sintasan udang vaname yang terinfeksi IMNV paling tinggi pada perlakuan Pro+Pre 3\% mencapai 2.9 kali lebih besar dibandingkan Kontrol (+) (Gambar 2). Widanarni et al. (2008) menyebutkan bahwa aplikasi bakteri probiotik SKT-b mampu meningkatkan kelangsungan hidup larva udang windu yang diinfeksi $V$. harveyi melalui perendaman sebesar $83.33 \%$ dibandingkan kontrol sebesar $41.67 \%$. Hasil penelitian lain juga menunjukkan bahwa pemberian bakteri SKT-b mampu meningkatkan sintasan hidup udang vaname yang diinfeksi $V$. harveyi sebesar $91.1 \%$ dibandingkan kontrol $46.7 \%$. Peningkatan sintasan ini dimungkinkan karena terjadinya peningkatan beberapa parameter respons imunitas berupa nilai total hemosit, aktivitas fagositosis dan aktivitas phenoloxidase (PO) (Syahailatua 2009). 


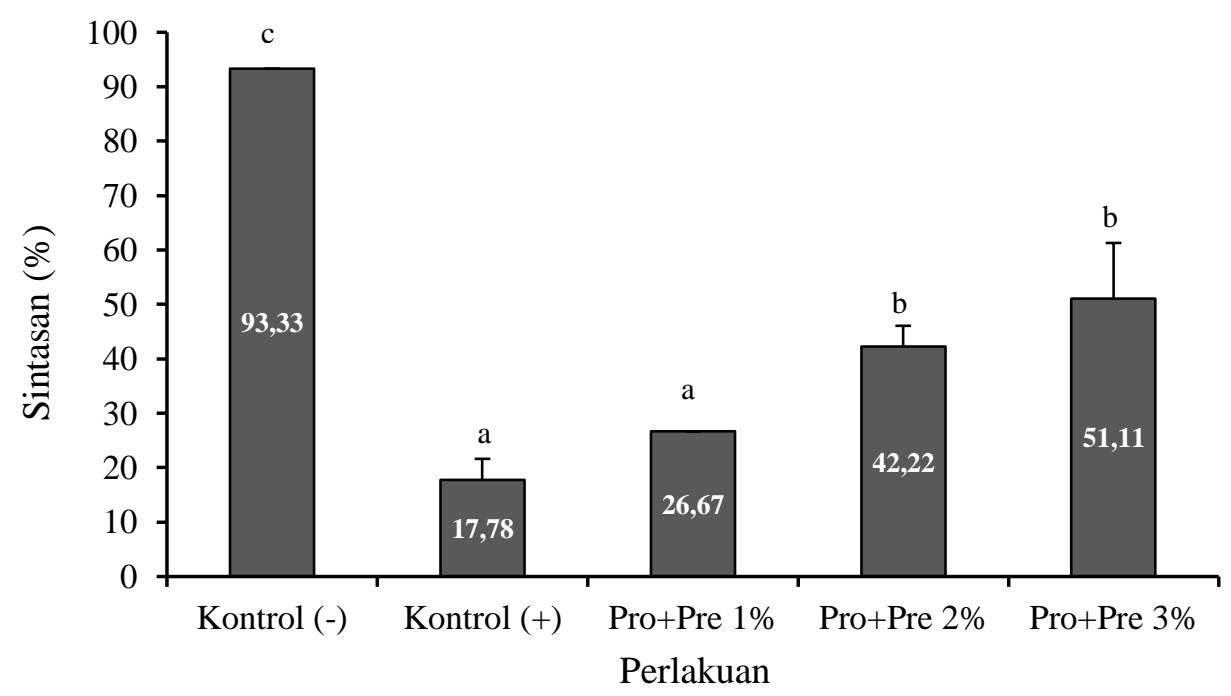

Gambar 2 Sintasan udang vaname berbagai perlakuan pakan pada hari ke 10 setelah infeksi IMNV ( $n=15)$. Angka pada kolom merupakan nilai rataan dan huruf yang berbeda menunjukkan perbedaan nyata (Tukey; $\alpha=0.05$ )

Udang vaname yang masih hidup hari ke 10 setelah infeksi pada perlakuan yang sama memperlihatkan gejala klinis yang berbeda-beda. Gejala klinis yang muncul menunjukkan tingkat infeksi IMN terhadap udang uji. Infeksi IMN dimulai dengan munculnya gejala klinis berupa lesi (nekrosis) keputih-putihan di otot bagian belakang. Nekrosis di otot pada stadia awal infeksi dapat sembuh yang ditandai dengan perubahan nekrosis dari coagulative ke liquefactive dan disertai dengan infiltrasi hemosit serta fibrosis. Pada tahap lanjut dari infeksi IMN, nekrosis kemudian meluas ke seluruh bagian otot abdomen, yang menyebabkan warna otot menjadi putih (tidak transparan) dan kemudian berlanjut ke perubahan warna otot menjadi kemerahan. Pada tahap ini, udang tidak dapat pulih dan berujung pada kematian (Lightner et al. 2004; Tang et al. 2005; Costa et al. 2009). Berdasarkan hasil pengamatan gejala klinis pada hari ke 10 setelah infeksi, Kontrol $(+)$ memperlihatkan tingkat infeksi paling berat yang diiringi dengan tingkat kematian yang tinggi. Pada perlakuan Sinbiotik masih ditemukan udang dengan tingkat infeksi ringan. Persentase udang dengan tingkat infeksi ringan dan sedang semakin tinggi seiring peningkatan dosis prebiotik. Udang perlakuan Pro+Pre 2\% dan Pro+Pre 3\% menunjukkan tingkat infeksi lebih ringan dan berbeda nyata dengan kontrol (+) (Gambar 3). Hal ini menandakan adanya peningkatan imunitas pada udang yang diberi perlakuan sinbiotik, sehingga dapat menurunkan tingkat infeksi dari INM. Pengamatan gejala klinis hanya dilakukan pada hari ke 10 setelah infeksi, sehingga tidak diketahui apakah udang yang diamati sedang dalam tahap penyembuhan ataukah akan menuju ke stadia yang lebih lanjut. Perlakuan Kontrol (-) pada penelitian ini menunjukkan terjangkit IMN sampai tingkat sedang. Diduga udang tertular selama pemeliharaan melalui air atau peralatan. 


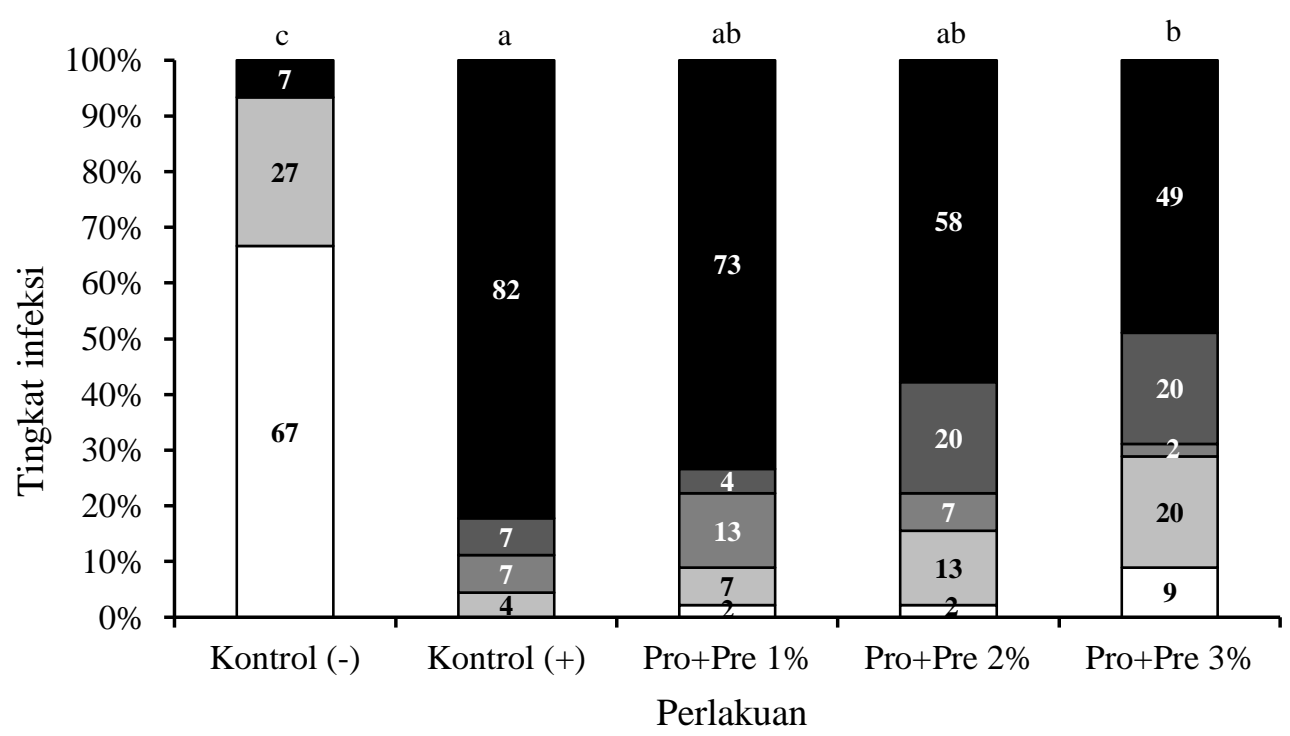

Gambar 3 Tingkat infeksi udang vaname berbagai perlakuan sinbiotik pada hari ke 10 setelah infeksi IMN ( $n=15)$. Simbol menunjukkan tingkat infeksi: mati $\square$ ), sangat berat ( $\square$ ), berat $\square$ ), sedang $(\square)$, ringan $(\square)$. Angka pada kolom merupakan nilai rataan dan huruf yang berbeda menunjukkan perbedaan nyata (Tukey; $\alpha=0.05$ )

\section{Total Hemosit (THC) dan Aktivitas Phenoloxidase (PO)}

Mekanisme pertahanan pada krustasea kurang berkembang dibandingkan dengan ikan dan vertebrata lainnya, dan hanya bergantung pada mekanisme pertahanan non spesifik. Hemosit memainkan peranan penting pada pertahanan tubuh krustasea yaitu dapat menghilangkan partikel asing yang masuk ke tubuh udang melalui fagositosis, enkapsulasi dan pembentukan nodul, serta produksi komponen-komponen humoral yang disimpan dalam granula hemosit diantaranya protein antikoagulan, aglutinin, enzim $\mathrm{PO}$, peptida antimikrobial, dan inhibitor protease (Jiravanichpaisal et al. 2006). Pemberian sinbiotik pada perlakuan Pro+Pre $2 \%$ dan Pro+Pre $3 \%$ selama 30 hari mampu meningkatkan nilai THC udang vaname sampai dengan dua kali nilai THC udang Kontrol pada awal pengamatan. Jumlah hemosit yang tinggi dalam darah udang ini sangat menguntungkan dalam mekanisme pertahanan tubuh, sehingga ketika udang terinfeksi IMN, sistem imunitas (dalam hal ini limfosit) dapat meminimalisir kerusakan akibat infeksi (menurunkan tingkat infeksi) dan meningkatkan sintasan.

Selama periode pengamatan parameter imunitas, nilai THC udang perlakuan Pro+Pre 2\% dan Pro+Pre 3\% memperlihatkan pola yang berbeda dengan perlakuan lainnya. Setelah infeksi virus IMN, nilai THC udang perlakuan Pro+Pre $2 \%$ dan Pro+Pre $3 \%$, terus mengalami penurunan sampai dengan akhir pengamatan (hari ke 10). Sebaliknya nilai THC perlakuan Protpre $1 \%$ dan Kontrol (+) baru menunjukkan peningkatan pada hari ke lima dan menurun kembali di akhir pengamatan (Gambar 4). Penurunan nilai THC udang perlakuan Pro+Pre $2 \%$ dan Pro+Pre 3\% mengindikasikan reaksi cepat terhadap infeksi yang diberikan. Penurunan jumlah hemosit ini merupakan efek dari berjalannya mekanisme pertahanan tubuh seperti infiltrasi hemosit pada jaringan yang 
terinfeksi, kematian sel hemosit akibat apoptosis (Costa et al. 2009), aktivitas fagositosis, enkapsulasi, pembentukan nodul, serta terjadinya proses degranulasi untuk aktivasi sistem prophenoloxidase (proPO) dan mekanisme pertahanan tubuh lainnya (Smith et al. 2003).

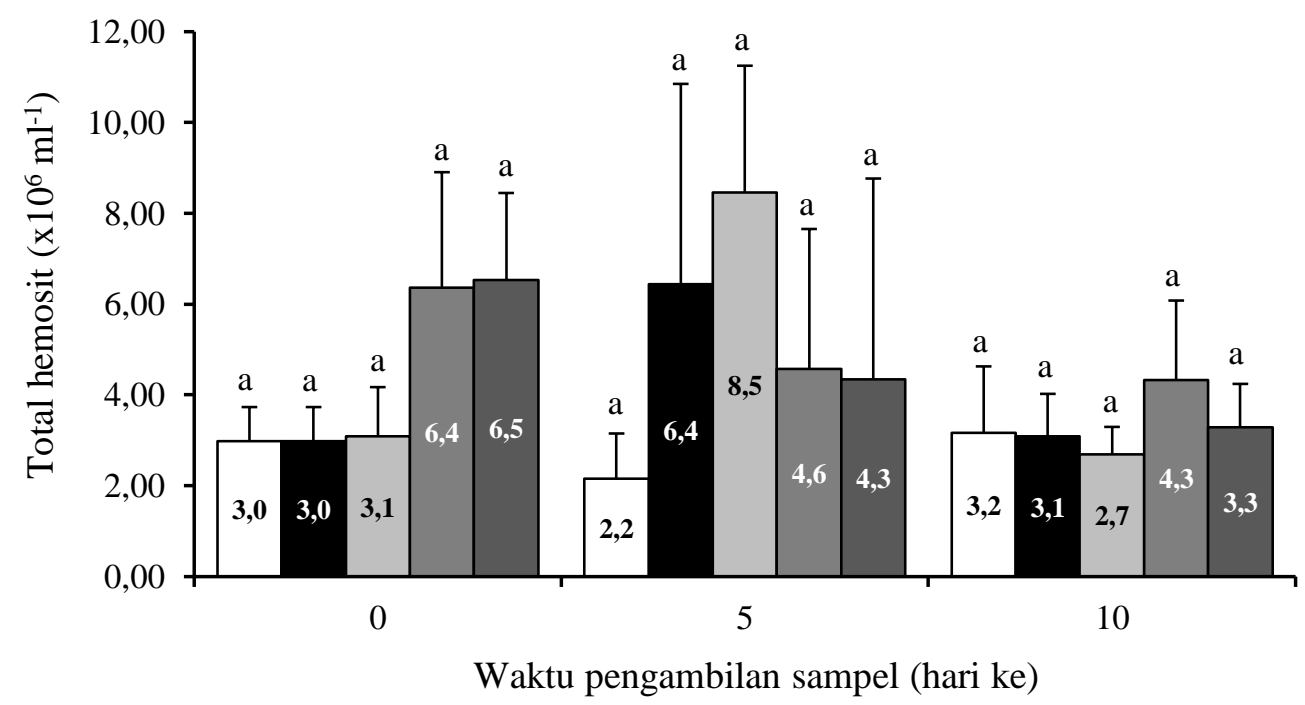

Gambar 4 Total hemosit udang vaname perlakuan: Kontrol (-) $\square$ ), Kontrol (+) $\square$ ),

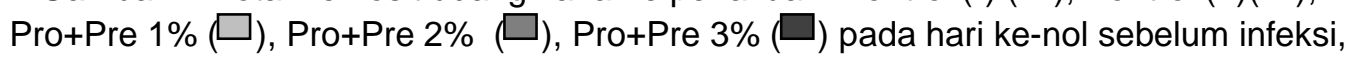
hari ke 5 dan ke 10 setelah infeksi IMN. Angka pada kolom merupakan nilai rataan dan huruf yang berbeda menunjukkan perbedaan nyata (Tukey; $\alpha=0.05$ )

Tingginya proses degranulasi dapat dilihat dari meningkatnya aktivitas PO. Aktivitas PO digunakan untuk mengukur aktivasi sistem proPO. Parameter imunitas ini adalah bagian dominan pada sistem pertahanan krustasea yang berperan dalam perilaku sel, pelepasan dan atau aktivasi molekul-molekul fungsional penting serta netralisasi agen penginfeksi (Smith et al. 2003). Infeksi IMN menyebabkan peningkatan aktivitas $\mathrm{PO}$ udang vaname sampai akhir pengamatan. Peningkatan aktivitas $\mathrm{PO}$ juga terjadi pada $P$. vannamei yang diinfeksi Taura Syndrome Virus (Song et al. 2003). Peningkatan aktivitas PO di hari ke lima setelah infeksi pada udang yang diberi perlakuan sinbiotik lebih tinggi dibandingkan dengan Kontrol (+) (Gambar 5). Aktivitas PO tertinggi ditunjukkan oleh perlakuan Pro+Pre $3 \%$ sebesar $0.46 \mathrm{PO}_{100 \mu \mathrm{L}^{-1}}$ pada hari ke 5 pengamatan dan meningkat menjadi $0.61 \mathrm{PO} 100 \mu \mathrm{L}^{-1}$ pada hari ke 10 pengamatan. Pola peningkatan aktivitas $\mathrm{PO}$ yang tajam pada udang perlakuan sinbiotik, terlihat pada hari ke 5 dan semakin meningkat pada pengamatan hari ke 10. Sebaliknya pada udang perlakuan Kontrol (+) pola peningkatan tajam terlihat di hari ke 10 . Hal ini menandakan respons imunitas udang perlakuan Kontrol (+) lebih lambat dibandingakan udang perlakuan sinbiotik. Respons imunitas yang lambat akan merugikan karena dapat memberikan kesempatan pada virus untuk memperbanyak diri dan menimbulkan kerusakan parah pada udang sehingga tidak memungkinkan lagi untuk memulihkan diri, yang akan berujung pada kematian udang. 


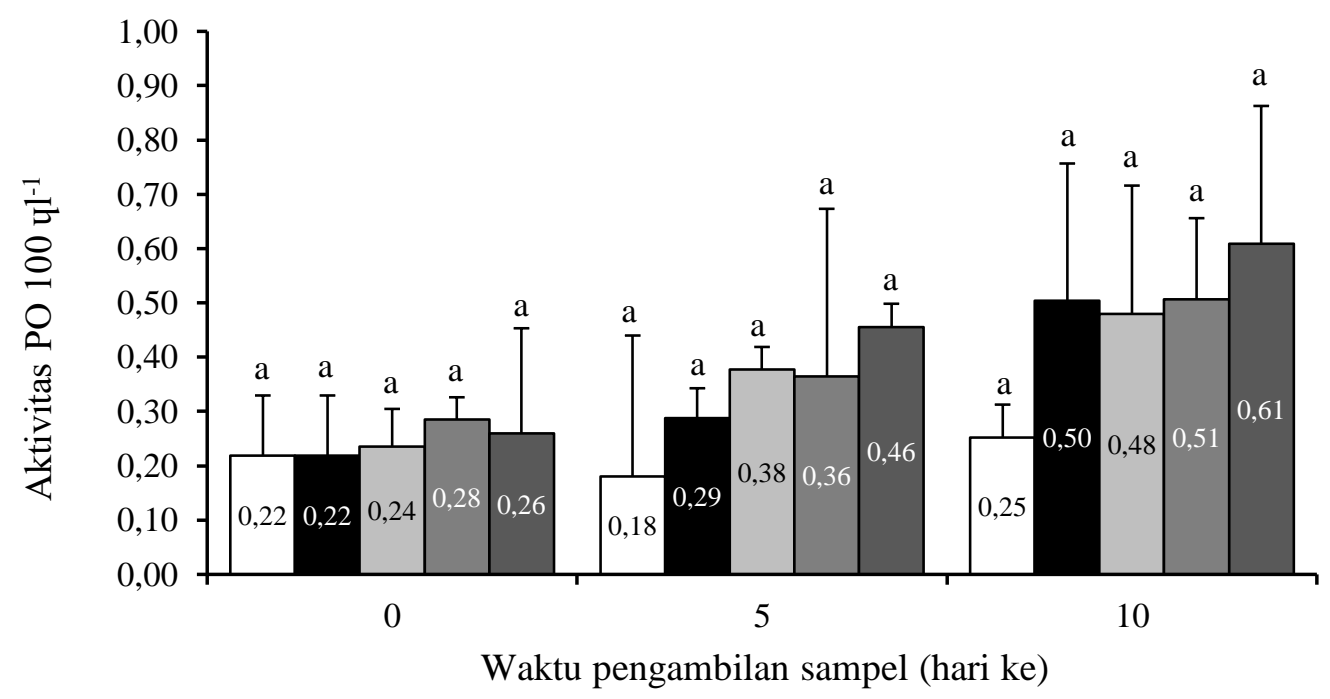

Gambar 5 Aktivitas PO udang vaname perlakuan: Kontrol (-) $(\square)$, Kontrol (+) $(\square)$, Pro+Pre 1\% $(\square)$, Pro+Pre 2\% $\square$ ), Pro+Pre 3\% $(\square)$ pada hari ke 0 sebelum infeksi, hari ke 5 dan ke 10 setelah infeksi IMN. Angka pada kolom merupakan nilai rataan dan

huruf yang berbeda menunjukkan perbedaan nyata (Tukey; $\alpha=0.05$ )

Hasil pengukuran parameter imunitas menunjukkan bahwa nilai THC dan aktivitas PO udang uji sangat bervariasi, bahkan pada udang dengan perlakuan dan ulangan yang sama. Hal ini dikarenakan setiap individu udang berada pada tingkat infeksi yang berbeda-beda (ditunjukkan dengan beragamnya gejala klinis yang muncul), sehingga menyebabkan perbedaan nilai parameter imunitasnya. Nilai dari parameter imunitas sangat tergantung pada kondisi fisiologis individu (Maggioni et al. 2004; Le Moullac et al. 1997) atau perubahan lingkungan (Le Moullac dan Haffner 2000). Keragaman nilai THC dan aktivitas PO individu udang ini menyebabkan standar deviasi antar perlakuan sangat tinggi sehingga hasil analisis statistik menunjukkan tidak berbeda nyata walaupun secara nominal memperlihatkan perbedaan yang sangat signifikan. Nilai parameter imunitas yang bervariasi ini juga dilaporkan oleh Costa et al. (2009) setelah menganalisis imunitas udang vaname di salah satu tambak di utara timur Brazil yang secara alami terinfeksi IMN, menunjukkan nilai standar deviasi yang tinggi antar perlakuannya.

Mekanisme probiotik dalam merangsang respons imunitas di usus pada ikan dan udang belum banyak dipelajari, sebaliknya interaksi antara probiotik dengan sistem imunitas usus pada hewan tingkat lebih tinggi telah terdokumentasi dengan baik (Nayak 2010). Pada mamalia, probiotik (bagian atau komponennya) dapat secara langsung meningkatkan imunitas dengan cara melewati sel epitel usus dan berinteraksi langsung dengan limfosit yang kemudian mengaktivasi respons imunitas (imunostimulasi). Secara tidak langsung, melalui kontak antara probiotik dengan sel epitel usus (gut associated lymphoid tissue [GALT]) yang akan mengakifkan sitokin sehingga memungkinkan terjadinya komunikasi antar sel untuk mengaktifkan respons imunitas (imunoregulator). Pemberian probiotik mempengaruhi fungsi limfosit (proliferasi, sekresi sitokin, dan sitotoksisitas seluler), pertahanan nonspesifik 
(fagositosis, produksi radikal oksidatif, sekresi enzim lisosom), fungsi sitosidal alami dari makrofaga dan sel-sel pembunuh, serta respons antibodi (total level antibodi dan respons spesifik antigen) (Gill dan Cross 2002).

Berdasarkan sedikit penelitian yang terkait dengan sistem imunitas di usus ikan, menunjukkan bahwa dalam usus ikan ditemukan banyak menyebar sel limfoid, makrofaga, granulosit dan IgM yang merupakan komponen imunitas. Probiotik mampu menstimulasi piscine gut immune system yang ditandai dengan meningkatnya jumlah sel $\mathrm{Ig}^{+}$dan granulosit asidofilik (AGs). Probiotik juga dapat mengarah pada peningkatan jumlah sel-T pada GALT di ikan. Penelitian lain menunjukkan adanya peningkatan gut mucosal lysozyme oleh $C$. maltaromaticum dan $C$. divergens serta aktivitas fagositik dari mucosal leucocyte oleh probiotik kelompok bakteri asam laktat seperti L. lasctis ssp. lactis, $L$. mesenteroides dan L. sakei pada ikan seperti O. Mykiss (Nayak 2010).

\section{SIMPULAN}

Aplikasi pemberian sinbiotik mampu meningkatkan resistensi udang vaname terhadap infeksi virus IMN. Peningkatan resistensi ini ditandai dengan meningkatnya sintasan udang dan menurunnya tingkat infeksi dari IMN yang diamati melalui gejala klinis. Peningkatan respon imun udang salah satunya dikarenakan peningkatan total leukosit dan aktivitas phenoloksidase. Secara umum, perlakuan Pro+Pre 2\% dan Pro+Pre 3\% menunjukkan respon yang lebih baik terhadap peningkatan resistensi udang vaname dibandingkan dengan perlakuan lainnya.

\section{DAFTAR PUSTAKA}

Blaxhall, Daishley KW. 1973. Routine haematological methods for use with fish blood. Journal Fish Biology 5: 577-581.

Costa AM, Buglione CC, Bezerra FL, Martins PCC, Barracco MA. 2009. Immune assessement of farm-reared Penaeus vannamei shrimp naturally infected by IMNV in NE Brazil. Aquaculture 291: 141-146.

Escobedo CM, Bonilla, Audoorn L, Wille M, Alday V, Sanz, Sorgeloos P, Pensaert MB, Nauwynck HJ. 2006. Standardized white spot syndrome virus (WSSV) inoculation procedures for intramuscular or oral routes. Dis Aquat Org 68: 181-188.

Gill HS, Cross ML. 2002. Probiotics and immune function. Di dalam: Calder PC, Field CJ, Gill HS, editor. Nutrition and Immune Function. UK: CABI Publishing.

Haryati T, Supriyati. 2010. Pemanfaatan senyawa oligosakarida dari bungkil kedelai dan ubi jalar pada ransum ayam pedaging. JITV 15(4): 253-260.

Hasan A. 2011. Ko-infeksi infectious myonecrosis virus (IMNV) dan Vibrio harveyi pada udang vaname (Litopenaeus vannamei) [tesis]. Bogor: Sekolah Pascasarjana IPB.

Jiravanichpaisal P, Lee BL, Soderhall K. 2006. Cell-mediated immunity in arthropods: hematopoiesis, coagulation, melanization and opsonization. Immunobiology 211: 213-236. 
Le Moullac G, Haffner P. 2000. Environmental factors affecting immune responses in crustacea. Aquaculture 191: 121-131.

Le Moullac G, Le Groumellec M, Ansquer D, Frosissard S, Levy P. 1997. Haematological and phenoloxidase activity changes in the shrimp Penaeus stylirostris in relation with the moult cycle: protection against vibriosis. Fish Shellfish Immunol 7: 227-234.

Lesmanawati W, Widanarni, Sukenda, Purbiantoro W. 2013. Potensi ekstrak oligosakarida ubi jalar sebagai prebiotik bakteri probiotik akuakultur. Jurnal Sains Terapan Vol. 3 (1) : 19-25.

Li J, Beiping T, Kangsen M. 2009. Dietary probiotic Bacillus OJ and isomaltooligosaccharides influence the intestine microbial populations, immune responses and resistance to white spot syndrome virus in shrimp (Litopenaeus vannameI). Aquaculture 291: 35-40.

Lightner DV, Pantoja CR, Poulos BT, Tang KFJ, Redman RM, Andrade TP, Bonami JR. 2004. Infectious myonecrosis: new disease in Pacific white shrimp. Glob Aquac Advocate 7: 85.

Liu $\mathrm{CH}$, Chen JC. 2004. Effect of ammonia on the immune response of white shrimp Litopenaeus vannamei and its susceptibility to Vibrio alginolyticus. Fish and Shellfish Immunology 16: 321-334.

Maggioni DS, Andreatta ER, Hermes EM, Barracco MA. 2004. Evaluation of some hemato-immunological parameters in female shrimp Litopenaeus vannamei submitted to unilateral eyestalk ablation in association with a diet supplemented with superdoses of ascorbic acid as a form of immunostimulation. Aquaculture 241: 501-515.

Marlis A. 2008. Isolasi oligosakarida ubi jalar (Ipomoea batatas L) dan pengaruh pengolahan terhadap potensi prebiotiknya [tesis]. Bogor: Sekolah Pascasarjana, Institut Pertanian Bogor.

Muchtadi D. 1989. Evaluasi Nilai Gizi Pangan. Depdikbud, Dirjen Dikti-PAU. Bogor : Institut Pertanian Bogor.

Nayak SK. 2010. Probiotics and immunity : a fish perspective. Fish and Shellfish Immunology 29: 2-14.

Putra AN. 2010. Kajian probiotik, prebiotik dan sinbiotik untuk meningkatkan kinerja pertumbuhan ikan nila (Oreochromis niloticus) [tesis]. Bogor : Sekolah Pascasarjana IPB.

Rodriguez-Estrada U, Satoh S, Haga Y, Fushimi H, Sweetman J. 2009. Effect of single and combined supplementation of Enterococcus faecalis, mannan oligosaccharide and polyhydrobutyric acid on growth performance and immune response of rainbow trout Oncorhynchus mykiss. Aquaculture science 57: 609-617.

Smith VJ, Brown JH, Hauton C. 2003. Immunostimulation in crustaceans: does it really protect against infection?. Fish Shellfish immunol 15: 71-90.

Song YL, Yu CI, Lien TW, Huang CC, Lin MN. 2003. Haemolymph parameters of pacific white shrimp (Litopenaeus vannamei) infected with taura syndrome virus. Fish and Shelfish Immunlogy 14: 317-331. 
Syahailatua DY. 2009. Seleksi bakteri probiotik sebagai stimulator sistem imun pada udang vaname Litopenaeus vannamei [Tesis]. Bogor : Sekolah Pascasarjana IPB.

Tang KFJ. Pantoja CR, Poulos BT, Redman RM, Lightner DV. 2005. In situ hybridization demonstrates that Litopenaeus vanammei, L. stylirostris and Penaeus monodon are susceptible to experimental infection with infectious myonecrosis virus (IMNV). Dis aquat Org 63: 261-265.

Taukhid, Nura'ini YL. 2008. Infectious myonecrosis virus (IMNV) in pasific white shrimp, Litopenaeus vannamei in Indonesia. Indonesian Aquaculture 3(2): 139-146.

Widanarni, Sukenda, Setiawati M. 2008. Bakteri probiotik dalam budidaya udang: seleksi, mekanisme aksi, karakterisasi dan aplikasinya sebagai agen biokontrol. Jurnal IImu Pertanian Indonesia 13 (2): 80-89.

Widanarni, Suwanto A, Sukenda, Lay BW. 2003. Potency of Vibrio isolates for biocontrol of vibriosis in tiger shrimp (Penaeus monodon) larvae. Biotropia 20: 11-23.

Zhang Q, Ma H, Mai K, Zhang W, Liufu Z, Xu W. 2010. Interaction of dietar Bacillus subtilis and fructooligosaccharide on growth performance, nonspecific immunity of sea cucumber, Apostichopus japonicas. Fish and Shellfish Immunology 29: 204-211. 